\title{
LEADERSHIP BEHAVIOUR MODELS OF KIAI ISLAMIC BOARDING SCHOOLS IN THE 4.0 INDUSTRIAL REVOLUTION ERA
}

\author{
Farhanudin Sholeh ${ }^{1}$ \\ Farhans.az17062013@gmail.com
}

\begin{abstract}
This study aims to describe the leadership behaviour model of Islamic boarding school Kiai in the industrial revolution 4.0 era at Assunniyyah Islamic Boarding School Kencong Jember and Miftahul Ulum Islamic Boarding School Banyuputih Kidul Lumajang. The type of research used is descriptive qualitative related to the leadership behaviour of the Kiai. The data analysis procedure is carried out continuously, simultaneously with data collection and then continued after data collection is carried out. The results of this study are 1). The similarities between the two pesantren are that the Kiai as caregivers both maintain the Islamic boarding school as a noble heritage from the founders of the pesantren, while 2). There are differences in leadership patterns. Pondok Pesantren Assunniyyah Kencong Jember radically separates salaf education from within the pesantren and modern education outside the pesantren. Meanwhile, at Miftahul Ulum Islamic Boarding School Banyuputih Kidul Lumajang, salaf and modern education are within the pesantren environment while still prioritizing salaf education.
\end{abstract}

Keywords: Leadership Behavior, Kiai, Islamic Boarding School, Industrial Revolution

\begin{abstract}
Abstrak: Penelitian ini bertujuan untuk mendiskripsikan model perilaku kepemimpinan kiai pesantren di era rovolusi industri 4.0 di Pondok Pesantren Assunniyyah Kencong Jember dan Pondok Pesantren Miftahul Ulum Banyuputih Kidul Lumajang. Jenis penelitian yang digunakan adalah deskriptif kualitatif terkait dengan perilaku kepemimpinan kiai. Adapun prosedur analisis data dilakukan secara terus-menerus, bersamaan dengan pengumpulan data dan kemudian dilanjutkan setelah pengumpulan data dilakukan. Hasil penelitian ini adalah 1). kesamaan antara dua pesantren yaitu kiai sebagai pengasuh sama sama mempertahankan kesalafan pesantren sebagai warisan luhur dari pendiri pesantren sedangkan 2). Terdapat perbedaan pola kepemimpian, Pondok Pesantren Assunniyyah Kencong Jember memisah secara radikal pendidikan salaf berada didalam pesantren, dan pendidikan modern berada di luar pesantren. Sedangkan di Pondok Pesantren Miftahul Ulum Banyuputih Kidul Lumajang pendidikan salaf dan dan modern sama sama berada dalam lingkungan pesantren dengan tetap mengutamakan pendidikan salaf.
\end{abstract}

Kata kunci: Perilaku Kepemimpinan, kiai, Pesantren, revolusi Industri

${ }^{1}$ Sekolah Tinggi Ilmu Syari'ah Miftahul Ulum Lumajang

Volume 12 Number 2 October 2021

Submitted: 12-08-2021Accepted: 27-09-2021 Approved: 29-09-2021 Published: 15-10-2021 


\section{Introduction}

The figure of the Kiai becomes a role model for the people in all aspects of the socio-cultural life of the community, and even in the political context, the Kiai often becomes the community's patronage in determining the political candidates. They will lead them in the next few years. So, as a leader and holder of a milestone in the glory of a pesantren, Kiai occupies a particular position in the community's hearts, especially the village community who will become role models in all aspects of life.

Babun Suharto said that the kiai is the central figure of every pesantren. Because Kiai is recognized as knowing, Kiai are also the founders, owners and waqf of the pesantren itself. A Kiai who cares for a pesantren struggles by sacrificing his energy, time, thoughts and even wealth in the context of Islamic symbols. Therefore, it is not excessive if the Kiai is made elders, role models, and a place to consult on religious and social issues for santri and the community (Suharto, 2011). Kiai is also a patron for the surrounding community and the wider community, especially regarding personality. As a patron, Kiai plays a role that is more than just a teacher. He not only places himself as a teacher and educator of his students but also actively solves crucial problems faced by society (problem-solving) (Gregbarton, 2008). In addition to having the depth of knowledge and istiqomah in his practice, a Kiai must also have a boarding school, a place for young people or students to gain religious knowledge in particular and general sciences in general.

\section{Literature Review}

\section{Kiai's Theory of Leadership}

The problem of leadership (Leadership) is an interesting discussion because it is one of the essential factors that influence the success or failure of an organization. Likewise, in Islamic boarding schools, a Kiai is one of the essential elements in driving activities in the Islamic boarding school.

Abdullah believed, as quoted by Nasir, and Kiai directly obtained the legitimacy of his leadership from the community. The community assesses the figure of the Kiai in terms of expertise in religious sciences. And not only that but the Kiai is also 
SYAIKHUNA: Jurnal Pendidikan dan Pranata Islam STAI Syichona Moh. Cholil Bangkalan p-ISSN:2086-9088, e-ISSN: 2623-0054

DOI: https://doi.org/10.36835/syaikhuna.v12i2.5117

judged on the authority that comes from knowledge, supernatural powers, personal traits and even descent (nasab) (Nasir, 2005).

The community views the Kiai as an ideal figure in the pesantren community and the Kiai representing their existence. The figure of the Kiai in this ideal view is significant both as a mediator, dynamist, catalyst, motivator and as a power for the community he leads (Nasir, 2005).

Koentjaraningrat distinguishes between leadership as a position and leadership as a social process. As a position, leadership is a complex of rights and obligations owed by a person or an entity. As a social process, leadership includes all actions taken by a person or an entity that causes societal movement (Koentjaraningrat, 1967).

There are three types of leaders: traditional, charismatic, and formal (rational) (Kartodirdjo 1976). Traditional leaders are rooted in a social structure organized by birth, wealth, and status. Charismatic leaders are rooted in their charisma. Formal leaders focus on the legal system prevailing in society.

As a result of the dynamics or demands of society, Islamic boarding schools make various efforts or steps that cause changes or shifts in the pattern of leadership carried out by the Kiai. Therefore, the pattern of leadership in managing and developing pesantren is not the same between one pesantren and another. Em Nadjib Hassan et al., in their research on Islamic boarding schools in Kudus, illustrate that the pattern or profile of the leadership of the Kiai in Kudus is quite varied. Kia's leadership profile in managing pesantren in Kudus has the following tendencies::

a. A Kiai with a community leadership profile is a Kiai known for his greatness, both for his greatness and for his pesantren, because the Kiai has a position or position in a socio-religious, political organization or has a position in specific power.

b. Kiai has a scientific leadership profile (intellectual leader), namely a Kiai who has personal greatness and pesantren because the Kiai is considered to have indepth scientific expertise, which is used as a reference or role model for the community in solving problems. The field of science is, for example, the science of jurisprudence, the science of hadith and others.

c. The Kiai has a spiritual leadership profile, namely a Kiai whose excellent private and Islamic boarding school. The Kiai has the ability in matters of worship 
SYAIKHUNA: Jurnal Pendidikan dan Pranata Islam STAI Syichona Moh. Cholil Bangkalan p-ISSN:2086-9088, e-ISSN: 2623-0054

DOI: https://doi.org/10.36835/syaikhuna.v12i2.5117

(mosque imam) to become a mursyid (teacher) of tariqah and becomes a religious, moral role model.

d. With an administrative leadership profile (administrative leader), Kiai only acts as a person in charge. At the same time, the guidance of the pesantren learning process is left to someone who is considered to have qualifications by the vision and mission of the pesantren.

e. Kiai with an inspirational leadership profile (emotional leader), namely the greatness of the kiai's leadership which is more based on the bonds of the greatness of a certain Kiai, the greatness of the Kiai is better known as an expert in specific sciences, both at local and national levels.

f. With an economic leadership profile, Kiai manages pesantren by implementing programs to empower the economic potential of the community and its students.

g. Kiai with exoteric leadership profile, namely Kiai who manage pesantren by highlighting the formal aspects of pesantren (2005: 68-70)

Kiai has an essential role in the development of pesantren. The role is the behaviour of individuals who perform a specific position concerning individuals in other positions. The role is a dynamic aspect of position (status) (Soekanto, 2003).

\section{Industrial Revolution 4.0}

The term "Industrial Revolution" was introduced by Friedrich Engels and Louis-Auguste Blanqui in the mid-19th century. This industrial revolution is also running from time to time. This last decade can be called entering the fourth phase 4.0. The change from phase to phase gives an articulative difference in terms of its usefulness. The first phase (1.0) revolves around discovering machines that emphasize (stressing) the mechanization of production. The second phase (2.0) has moved on to the mass production stage integrated with quality control and standardization. The third phase (3.0) enters the stage of mass uniformity, which is based on computerized integration. The fourth phase (4.0) has presented digitalization and automation of the combination of the internet with manufacturing (Suwardana, 2017: 102-110).

The fruit of industrial revolution 4.0 is the emergence of the phenomenon of disruptive innovation. The impact of this phenomenon has spread in all areas of life. 
We are starting from industry, economy, education, politics, And so on. This phenomenon has also succeeded in shifting the lifestyle and mindset of the world community. Disruptive innovation can be interpreted as a phenomenon of disruption of the old industry players (incumbent) by new industry players due to the convenience of information technology.

One of the many examples around us is the declining income of grocery stores. This decline in income was not caused by a decrease in the number of buyers and lack of interest but a change in consumer behaviour. Due to advances in information technology, online buying and selling companies have emerged, such as Bukalapak, Lazada, Shopee, JD.ID and many other online stores whose services are based on internet applications. Consumers only need to install an application on their smartphones to use their services. In addition, the installed rates are much cheaper. This new online store is what causes conventional store incumbents to suffer losses.

In addition, the phenomenon of disruptive innovation also causes several professions to disappear because machines replace them. For example, now all the work of check-in counter officers at various international airports has been taken over by machines that can directly answer passenger needs, including scan machines to check passports and visas, as well as printers to print boarding passes and luggage tags (Kasali, 2017: 16). ). Another impact is the emergence of new professions that did not exist before, such as Youtubers, Website Developers, Bloggers, Game Developers, Etc.

The advantages of the emergence of disruptive innovation include: First, it is easier for consumers to meet their needs. By cutting costs, companies that use the latest technology can keep costs down to charge much lower prices than incumbent companies. Thus, the cheaper the costs incurred by consumers, the more prosperous consumers are.

Second, technology makes it easy. The emergence of innovations will undoubtedly bring new and sophisticated technology, at least compared to the technology that has existed for a long time. Thus it can be said that there is a transfer of technology to a more modern one. Third, spur innovation-based competition. Indonesia is a country that cannot simply prosper without innovation. With disruptive innovation, companies in the industry are forced to innovate to continue to improve their services. 
Fourth, reduce the number of unemployed. The innovations made will provide new job opportunities. If it does not open up new fields, at least it can expand existing jobs. Moreover, innovation can provide new job opportunities with better wages than those from existing jobs. Fifth, increase economic growth. Disruptive technology, according to Schumpeter's theory, will increase productivity due to efficiency. With these two things, it will increase the quality and quantity of goods produced.

On the other hand, innovation will also increase people's consumption after previously increasing their income. The development that became the endpoint was the increase in the number of Gross Domestic Product. If each innovation can generate more excellent added value and relatively lasts every year, it will increase economic growth in the long term.

\section{Research methods}

The type of research used is descriptive qualitative. The qualitative descriptive method is a research method that aims to describe a social phenomenon or natural phenomenon in a systematic, factual and accurate manner. A qualitative method is a research procedure that will produce qualitative data in written or spoken words from people or an experimental process (Miles, 2014).

Researchers determined the location at the Assunniyah Islamic Boarding School in Kencong Jember and Miftahul Ulum Islamic Boarding School Banyuputih Kidul Jatiroto Lumajang. In this study, the informant determination technique used was purposive. Purposive is a technique of taking informants with specific considerations (Sugiyono, 2008). These considerations are informants who understand and carry out the leadership of the Kiai. The key informant in this study was KH. Ahmad Sadid Jauhari as caretaker of the Islamic boarding school Assunniyah Kencong Jember and KH. Husni Zuhri as caretaker of Miftahul Ulum Islamic Boarding School Banyuputih Kidul Jatiroto Lumajang.

Data collection procedures in this study used three ways, namely: (1) In-depth interviews. This method aims to obtain certain forms of information from all respondents, but the wording and order are adjusted to the characteristics of each respondent; (2) Observations which are direct or indirect observations through existing facts and data, so in the application of this method a particular systematic recording of 
SYAIKHUNA: Jurnal Pendidikan dan Pranata Islam STAI Syichona Moh. Cholil Bangkalan p-ISSN:2086-9088, e-ISSN: 2623-0054

DOI: https://doi.org/10.36835/syaikhuna.v12i2.5117

the phenomena investigated is related to the physical evidence in the field found by the researcher; and (3) Documentation study which aims to reveal activities and actions that can increase the researcher's understanding of the problems studied. This documentation study allows finding differences or contradictions between the interviews and observations with the results contained in the document.

The data analysis procedure is carried out continuously, simultaneously with data collection and then continued after data collection is carried out. According to Miles, Huberman and Saldana (2014), three flows of activities coinciding in qualitative data analysis. Activities in data analysis are (1) Data Condensation (Data Condensation); (2) Data Display (Data Display); and (3) Conclusion Drawing/Verifications.

In this study, several criteria were used to check the validity of the data, namely: (1) Credibility test; (2) Transferability; (3) Dependability and confirmability (Sugiyono, 2008).

\section{Results and Discussion}

Assunniyah Islamic Boarding School led by KH. Ahmad Sadid Jauhari is a federation of five Islamic boarding schools. The term "Federation" is taken from the designation of the Annuqayyah Guluk-guluk Islamic Boarding School in Sumenep Madura used by. Abd. Halim Soebahar, in a book entitled "Islamic Boarding School Modernization; Study of Kiai Leadership Transformation and Islamic Boarding School Education System", The author adopted the language of "Federation" because there is a similarity in the management of the Assunniyah Kencong Jember Islamic Boarding School with the Annuqoyyah Guluk-guluk Islamic Boarding School in Sumenep Madura. Where the parent boarding school is the Assunniyah Islamic Boarding School. Meanwhile, the federation boarding school is a boarding school that was pioneered by relatives, sonsin-law, nephews and even alumni of the Assunniyah Islamic Boarding School who have lived in the cottage area for a long time. In mapping the federation pesantren, it is adjusted to the competence and orientation of each caregiver, but in general, the five pesantren focus on teaching religious sciences. (doc. Assunniyyah, 2015).

KH. Ahmad Sadid Jauhari is a 2nd generation Assunniyah Kencong Islamic boarding school caretaker after the death of KH. Djauhari Zawawi, the father of Kiai 
SYAIKHUNA: Jurnal Pendidikan dan Pranata Islam STAI Syichona Moh. Cholil Bangkalan p-ISSN:2086-9088, e-ISSN: 2623-0054

DOI: https://doi.org/10.36835/syaikhuna.v12i2.5117

Sadid (KH. Ahmad Sadid Jauhari as he was affectionately known) in 1994. Unlike other pesantren, the change of leadership was left to the founder's first son or caregiver. However, Kiai Sadid as the second son, replaced his father's leadership in leading the Assunniyyah Islamic boarding school. Kiai Sadid is four sons of the late Alm. KH. Jauhari Zawawi, namely KH. Fahim Jauhari (late), KH. Ahmad Sadid Jauhari, KH. Rosiful Aqli and KH. A. Ghanim Djauhari.

Assunniyah Islamic Boarding School and its federation have their development focus on educating their students. Assuniyah itself, as the primary boarding school, focuses on the education of students on the religious aspect. However, there is formal education only to support and not required. Meanwhile, one of the federation boarding schools raised by his son-in-law, the Ali Ba'alwi Islamic Boarding School, focused on purely religious aspects.

Efforts to deal with the 4.0 industrial revolution at the Assunniyah Kencong Islamic boarding school are preparing Islamic higher education institutions established by the caregivers of the Assunniyah Islamic boarding school. However, the institution is located separately from the Islamic boarding school. Even as if it has nothing to do with the boarding school. This shows an effort to maintain Islamic boarding schools as salaf boarding schools and, on the other hand, trying to prepare to face the industrial revolution 4.0 in Assunniyah Islamic boarding schools. Until PP. Assunniyah radically separates the pattern of Salafi and kholafi education. Islamic boarding school-style salaf education focuses on boarding schools while education that is oriented and intersects with IT is outside the pesantren.

Meanwhile, Miftahul Ulum Islamic Boarding School Banyuputih Kidul Lumajang led by KH. Muhammad Husni Zuhri is a pesantren with a single leadership, where $\mathrm{KH}$. Muhammad Husni Zuhri as a caregiver, has sole authority in making decisions in his leadership. While the management carries out the pattern of an embodiment of the policies taken, almost all of whom are senior students. (doc. PPMU Bakid, 2018).

KH. Muhammad Husni Zuhri is the 3rd generation Caregiver of Miftahul Ulum Islamic Boarding School Banyuputih Kidul Lumajang after the death of KH. Zuhri Sirojuddin, the parents of Kiai Husni (KH. Muhammad Husni Zuhri's nickname), the leadership of the 2nd generation, was handed over to the founder's first son-in-law or caretaker, KH. Muhammad Toyyib Rofi'i because kyai Husni is currently studying in Makkah Al-Mukarramah under Al-Allamah Hadratus Shaykh Isma'il bin Zain Al-Yamani. 
SYAIKHUNA: Jurnal Pendidikan dan Pranata Islam STAI Syichona Moh. Cholil Bangkalan p-ISSN:2086-9088, e-ISSN: 2623-0054

DOI: https://doi.org/10.36835/syaikhuna.v12i2.5117

Then in 1990, KH. M. Thayyib Rafi'i handed over the leadership of PPMU to KH. M. Husni Zuhri, the youngest son of KH. Zuhri Sirajuddin is the 3rd generation caregiver. After handing over the PPMU leadership relay to KH. M. Husni Zuhri, who is also his brother-in-law, KH. M. Tayyib pioneered the establishment of a new pesantren which became known as the "Bustanul Ulum" Islamic Boarding School (PPBU), which is located not far from PPMU, namely in Karang Baru Hamlet, Banyuputih Kidul Village.

The caretaker of the Miftahul Ulum Islamic Boarding School, Banyuputih Kidul Lumajang, focuses on educating its students. The caretaker of the Miftahul Ulum Islamic Boarding School, Banyuputih Kidul Lumajang, focuses on the education of students on the religious aspect. However, there is formal education only to support and not required.

Efforts are being made to deal with the 4.0 industrial revolution at the Miftahul Ulum Islamic Boarding School in Banyuputih Kidul Lumajang, namely, preparing an Islamic higher education institution that was founded by the caretaker of the Miftahul Ulum Islamic Boarding School in Banyuputih Kidul Lumajang in contrast to the leadership pattern of the Assunniyyah Kencong Islamic Boarding School in Jember, the Miftahul Ulum Islamic Boarding School Caretaker Banyuputih Kidul Lumajang education that was established was in a pesantren environment and also under the guidance of a pesantren foundation. This shows an effort to maintain higher education and integrate it with the values of Islamic boarding schools without eliminating the mistakes of the pesantren itself to try to prepare for the industrial revolution 4.0.

The explanation above illustrates that a Kiai as the leader of a boarding school seeks to prepare for the industrial revolution 4.0. However, in preparing it, he still pays attention to and maintains the salafiyah traditions established as the initial foundation for establishing the Assunniyah Kencong Islamic Boarding School and the Miftahul Ulum Boarding School. Therefore, fundamental conditions are appropriate to be a model for the leadership behaviour of pesantren Kiai in the era of industrial revolution 4.0 .

\section{Conclusion}

In this research, it can be concluded that: The leadership behaviour model of Islamic boarding school Kiai in the industrial revolution 4.0 era at Assunniyyah Islamic 
SYAIKHUNA: Jurnal Pendidikan dan Pranata Islam STAI Syichona Moh. Cholil Bangkalan p-ISSN:2086-9088, e-ISSN: 2623-0054

DOI: https://doi.org/10.36835/syaikhuna.v12i2.5117

Boarding School Kencong Jember and Miftahul Ulum Islamic Boarding School Banyuputih Kidul Lumajang have similarities, namely the Kiai as caregivers both maintain the Islamic boarding school as a noble legacy from the founder of the pesantren because The leadership found in the two pesantren are both continuing the relay of the predecessors who founded the pesantren with the values of the Islamic boarding school's kesafan. In implementing the leadership behaviour of Islamic boarding school Kiai in the era of industrial revolution 4.0 at the Assunniyyah Islamic Boarding School Kencong Jember and the Miftahul Ulum Islamic Boarding School Banyuputih Kidul Lumajang, there are differences in welcoming the industrial revolution 4.0 era. Islamic Boarding School of Assunniyyah Kencong Jember still maintains the error of the pesantren and does not make adjustments within the pesantren. However, the Kiai caregivers make efforts to fortify and balance from outside the pesantren, namely by establishing higher education institutions outside the pesantren that continue to innovate and transform starting from STAI and turned into an institute is preparing to become a university. Meanwhile, Miftahul Ulum Islamic Boarding School Banyuputih Kidul Lumajang established formal educational institutions in Islamic boarding schools integrated with information technology, such as MA skills, high schools and IT BLKs that included students' skills in the IT field but did not eliminate Islamic boarding school values.

\section{REFERENCES}

Gregbarton, (2008). The Authorized Biography of Abdurrahman Wahid. Yogyakarta: LkiS Hassan, Em Nadjib, at.al.,(ed)., (2005). Profil Pesantren Kudus. Kudus: Cermin Koentjaraningrat, (1967). Beberapa Pokok Antropologi Sosial. Jakarta: Dian Rakyat

Kartodirdjo, Sartono, (1976). Kepemimpinan dalam Sejarah Indonesia. Yogyakarta: Balai Pendidikan dan Administrasi UGM

Miles, Metthew B, A. Michael Huberman and Johnny Saldana, (2014), Qualitative Data Analysis, A Methods Sourcebook, Sage Publications, Inc.

Nasir, Ridlwan. (2015). Mencari Tipologi Format Pendidikan Ideal Pondok Pesantren di Tengah Arus Perubahan. Yogyakarta: Pustaka Pelajar 
SYAIKHUNA: Jurnal Pendidikan dan Pranata Islam STAI Syichona Moh. Cholil Bangkalan p-ISSN:2086-9088, e-ISSN: 2623-0054

DOI: https://doi.org/10.36835/syaikhuna.v12i2.5117

Kasali, Rhenald. (2017). Disruption "Tak Ada yang Tak Bisa Diubah Sebelum Dihadapi Motivasi Saja Tidak Cukup" Menghadapi Lawan-Lawan Tak Kelihatan dalam Peradaban Uber. Jakarta: PT Gramedia Pustaka Utama

Soekanto, Soerjono. (2003). Sosiologi Suatu Pengantar. Jakarta: Raja Grafindo Persada

Suharto, Babun. (2011). Dari Pesantren untuk Ummat, Reinventing Eksistensi Pesantren di Era Globalisasi. Suarabaya: Imtiyaz

Sugiyono, (2008), Metode Penelitian Kuantitatif, Kualitatif Dan RED, Bandung: Alfabeta

Suwardana, Hendra. (2017) Revolusi Industri 4. 0 Berbasis Revolusi Mental, JATI UNIK, Vol.1, No.2 